\title{
Virulence Phenotypes of Puccinia triticina in the South Atlantic States in 1999
}

\author{
J. A. Kolmer, Research Plant Pathologist, USDA-ARS Cereal Disease Laboratory, Department of Plant Pathology, \\ University of Minnesota, St. Paul 55108
}

\begin{abstract}
Kolmer, J. A. 2002. Virulence phenotypes of Puccinia triticina in the South Atlantic states in 1999. Plant Dis. 86:288-291.

Collections of Puccinia triticina were made from rust-infected wheat leaves in Georgia, South Carolina, North Carolina, and Virginia in 1999 to examine if these states can be considered as a single epidemiological unit for virulence phenotypes of the wheat leaf rust pathogen. Singleuredinial isolates derived from the leaf rust collections were processed for identification of virulence phenotypes on seedling plants in greenhouse tests. Twenty-one virulence phenotypes from 253 isolates were described based on infection type to 16 Thatcher wheat lines near-isogenic for leaf rust resistance genes. Virulence phenotype MBRK (virulent to leaf rust resistance genes Lr1, Lr3, Lr3ka, Lr11, Lr30, Lr10, Lr14a, and Lr18) was the most common phenotype in the region, at $38.7 \%$ of all isolates. Phenotype TLGF (virulent to $L r 1, L r 2 a, L r 2 c, L r 3, L r 9, L r 11$, Lr14a, and Lr18) was the second most common phenotype overall, at $33.8 \%$ of isolates. Twenty-nine isolates selected on the basis of seedling virulence phenotypes also were tested for virulence to adult wheat plants with the resistance genes $\operatorname{Lr} 12, \operatorname{Lr} 13, \operatorname{Lr} 22 b$, and $\operatorname{Lr} 34$. In all, 23 isolates were avirulent to $\operatorname{Lr} 12$ and 26 isolates were virulent to $\operatorname{Lr} 13$. All isolates had fewer and smaller uredinia on the Thatcher line with $L r 34$ compared with Thatcher. The widespread occurrence of the predominant $P$. triticina virulence phenotypes throughout the region indicated that the South Atlantic states should be considered as a single epidemiological area for wheat leaf rust. Some virulence phenotypes which occurred at lower frequencies were found primarily in the Coastal Plain and mountains of North Carolina or in breeding plots in southern Georgia. Localized populations of $P$. triticina may develop in the South Atlantic region due to overwintering of leaf rust infections or specific selection by leaf rust resistance genes in wheat cultivars.
\end{abstract}

Additional keywords: epidemiology, Puccinia recondita f. sp. tritici, specific resistance genes

Leaf rust of wheat, caused by Puccinia triticina Eriks., occurs nearly wherever wheat is grown in the United States and worldwide (7). In the southeastern United States, southern soft red winter wheat is grown from Virginia to eastern Texas and Arkansas. In eastern Virginia, wheat is planted from late October to the first week of November, and harvested in the last 2 weeks of June. In North Carolina, wheat is planted from late October through the middle of November, and the harvest is completed by mid-June. Most of the wheat production fields in North Carolina are in the Coastal Plain region along the Atlantic coast that runs from Wilmington in the south to the northern border with Virginia. In South Carolina, wheat is seeded in the first 2 weeks of November, and harvested in the first 2 weeks of June. In Georgia, wheat is planted from the second week to

Corresponding author: J. A. Kolmer

E-mail: jkolmer@cdl.umn.edu

Accepted for publication 6 November 2001.

Publication no. D-2002-0104-01R

This article is in the public domain and not copyrightable. It may be freely reprinted with customary crediting of the source. The American Phytopathological Society, 2002. the end of November, and harvest is usually completed by the end of May.

Leaf rust infections have been observed as early as February in breeding plots at Plymouth, NC. The wheat crop at this time of year has not yet developed stems and is primarily leaves that are prostrate on the ground. Rust observations at this early date generally indicate that weather conditions have been favorable for the establishment of leaf rust infections on wheat during the preceding fall. The rust infections that overwinter are initially observed in scattered and isolated foci. In years in which leaf rust does not become established in the fall, or survive the winter, the initial leaf rust infections may not be observed until the middle of March. In those years, the initial inoculum must arrive on the southerly winds from Georgia and South Carolina. Weather conditions along with host resistance directly influence the establishment of leaf rust in the fall and survival through the winter. Extremely hot and dry weather in the preceding summer can reduce the amount of leaf rust inoculum present on volunteer wheat. Dry conditions in the fall following wheat planting also can limit leaf rust infection. Widespread overwintering of leaf rust does not occur every year in North Carolina, because the weather conditions are not always suitable.
In years in which overwintering does occur, the early development of rust infections can lead to higher levels of localized rust infections in April and early May.

Severity of leaf rust infections are usually low through the first weeks of April on susceptible wheat cultivars in the Coastal Plain region of North Carolina. The severity of leaf rust infections increases in late April and reaches maximum levels in the first 2 weeks of May. Leaf rust development in the Piedmont region of North Carolina occurs later, often shortly before the wheat reaches maturity in late May and early June.

The $P$. triticina population in the southeastern United States generally is considered to be distinct when compared with other regional populations in North America $(2,4,5)$. The predominant virulence phenotypes of $P$. triticina in the Southeast have been different from those in the southern and northern Great Plains, Ohio Valley, and the Pacific Northwest. The objective of this study was to identify virulence phenotypes of $P$. triticina sampled from different geographic regions of North Carolina, and also from locations in Georgia and South Carolina, to determine if the South Atlantic region could be considered as a homogeneous epidemiological unit for P. triticina.

\section{MATERIALS AND METHODS}

Wheat leaves with leaf rust infections were collected from three regions in North Carolina in early May and June of 1999. Samples from the Coastal Plain of North Carolina were collected from breeding plots at Kinston and Plymouth and from farm fields. Leaf rust collections for the Piedmont region were made from wheat plots at Clayton. Plots of susceptible wheat at Laurel Springs in the mountains of western North Carolina were sampled for leaf rust in the first week of June. Collections also were obtained from wheat breeding plots at Plains and Griffin in southern and central Georgia, respectively. Collections were obtained from plots at Blackwell and Barnwell in southwest South Carolina, and from Clemson in western South Carolina. Collections were obtained from plots at Blacksburg in western Virginia, and from and Holland and Painter in southeast Virginia.

Urediniospores from the leaf rust collections were inoculated onto 7-day-old seedlings of the wheat cultivar Thatcher that had been treated with $20 \mathrm{ml}$ of a maleic hydrazide $(\mathrm{MH})$ solution (5 g MH per 15 
liters $\mathrm{H}_{2} \mathrm{O}$ ) to prevent emergence of secondary leaves and to increase the size of uredinia. One week after inoculation, the leaves were trimmed so that only one uredinium remained on each plant. Two weeks after inoculation, when secondary rings had formed, spores from a single uredinium were collected with a cyclone spore collector into a 00 gelatin capsule. Soltrol 170 light industrial oil $(330 \mu \mathrm{l})$ was added to each capsule, and the spore suspensions were atomized onto 1-weekold seedling differential sets composed of 16 Thatcher near-isogenic lines of wheat, each with a different gene for leaf rust resistance. The differential sets were planted in fiber flats $(20$ by $25 \mathrm{~cm})$ that were filled with a sand-peat-soil mixture. The 12 Thatcher differentials (Lrl, Lr2a, Lr2c, Lr3, Lr9, Lr16, Lr24, Lr26, Lr3ka, $L r 11, L r 17$, and Lr30) used to describe virulence phenotypes of $P$. triticina (3) were used along with the isogenic lines that have $\operatorname{LrB}, \operatorname{Lr} 10, \operatorname{Lr} 14 a$, and $\operatorname{Lrl} 8$. After the oil evaporated (approximately 1 $\mathrm{h}$ ), the seedling flats were placed in a $100 \%$ humidity chamber for $16 \mathrm{~h}$. All plants were then maintained on a greenhouse bench between 18 and $25^{\circ} \mathrm{C}$ with supplemental metal halide lighting. Three single uredinial isolates from each collection were evaluated for virulence phenotype. Infection types on the differentials were read 12 days after inoculation. Each singleuredinial isolate was assigned a four-letter virulence phenotype description based on high or low infection type to the differentials and supplemental lines, according to the established nomenclature (3).

Twenty isolates of $P$. triticina that were selected based on their virulence pheno- types to the 16 differential lines also were tested for virulence to Thatcher lines with genes Lr3bg, Lr14b, Lr15, Lr19, Lr20, Lr21, Lr23, Lr25, Lr28, Lr29, Lr32, Lr33, and $L r 45$. The same procedures that were used for the standard set of 16 differentials were used to inoculate the additional differentials and evaluate the $P$. triticina isolates for infection type. Twenty-nine isolates also were tested for virulence to adult plants of Thatcher lines with the adult plant genes Lr12, Lr13, and Lr34. Four plants (one each of Thatcher lines with Lr12, Lr13, Lr34, and Thatcher) were grown together to heading stage in $15-\mathrm{cm}-$ diameter pots in a greenhouse at 18 to $25^{\circ} \mathrm{C}$ with supplemental metal halide lighting. Plants were trimmed such that two tillers remained on each plant. The flag leaves of each pot of plants were inoculated at anthesis with a single isolate by atomizing 2 to $3 \mathrm{mg}$ of urediniospores mixed with oil. Incubation and growth conditions were the same as for the seedling tests. Infection types were read in the same manner as for the seedling tests on the flag leaves of each plant 14 days after inoculation.

\section{RESULTS}

Virulence phenotype distribution. In all, 253 isolates of $P$. triticina collected from the South Atlantic region in 1999 were tested for virulence phenotype. Twenty-one virulence phenotypes were described based on infection types to the Thatcher near-isogenic lines (Table 1). A total of 6 phenotypes were found in collections from Georgia, 13 from South Carolina, 15 from North Carolina, and 4 from Virginia. Virulence phenotype MBRK (virulence to genes $L r 1, L r 3, L r 3 k a, L r 11$, Lr30, Lr10, Lr14a, and Lr18) was the most common phenotype in Georgia, South Carolina, and North Carolina, and was the second most common isolate from Virginia. MBRK was the most common phenotype across all locations, occurring at $38.7 \%$ of all isolates. Phenotype TLGF (virulent to $L r 1, L r 2 a, L r 2 c, L r 3, L r 9$, $L r 11, L r 14 a$, and Lrl8) was the second most common phenotype in Georgia, South Carolina, and North Carolina, and was the most common phenotype in Virginia. TLGF was the second most common phenotype across all locations at $33.8 \%$ of all isolates.

Some virulence phenotypes that occurred at lower frequencies were found in isolated locations in the South Atlantic region. Phenotype KCGD was found only at Plains, GA. Five isolates of phenotype TFGJ and nine isolates of TNRJ also were found in Plains, GA. Phenotypes MBGK and MCGS were found only at Blackville, SC and phenotype MBRJ was found only once at Barnwell, SC. No phenotypes were unique to the $P$. triticina collections from Virginia.

In North Carolina, phenotype MBRK was the most common virulence phenotype in the Coastal Plain, Piedmont, and Mountain regions. TLGF was the second most common phenotype in the Coastal Plain, MCRK was the second most common in the Piedmont, and LBBK was the second most common in the Mountain region. Fourteen, five, and six virulence phenotypes were found in the Coastal Plain, Piedmont, and Mountain regions, respectively. Eight isolates of LBBK, five isolates of FBMT, and four isolates of

Table 1. Number and frequency (\%) of isolates of Puccinia triticina identified for virulence phenotype on 16 lines of Thatcher wheat near-isogenic for leaf rust resistance genes in the South Atlantic states in 1999

\begin{tabular}{|c|c|c|c|c|c|c|c|c|c|c|c|}
\hline \multirow{3}{*}{$\begin{array}{l}\text { Virulence } \\
\text { phenotype }\end{array}$} & \multirow{3}{*}{$\begin{array}{l}\text { Virulences } \\
\text { ( } \operatorname{rr} \text { genes) }\end{array}$} & \multicolumn{10}{|c|}{ Isolates of Puccinia tritticina } \\
\hline & & \multicolumn{2}{|c|}{ Georgia } & \multicolumn{2}{|c|}{ South Carolina } & \multicolumn{2}{|c|}{ North Carolina } & \multicolumn{2}{|c|}{ Virginia } & \multicolumn{2}{|c|}{ Total } \\
\hline & & No. & $\%$ & No. & $\%$ & No. & $\%$ & No. & $\%$ & No. & $\%$ \\
\hline FBMT & $2 c, 3,3 \mathrm{ka}, 30, \mathrm{~B}, 10,14 a, 18$ & 0 & 0.0 & 0 & 0.0 & 8 & 5.6 & 0 & 0.0 & 8 & 3.2 \\
\hline FBRT & $2 c, 3,3 \mathrm{ka}, 11,30, \mathrm{~B}, 10,14 a, 18$ & 0 & 0.0 & 0 & 0.0 & 5 & 3.5 & 0 & 0.0 & 5 & 2.0 \\
\hline KCGD & $2 a, 2 c, 3,26,11,14 a$ & 6 & 13.6 & 0 & 0.0 & 0 & 0.0 & 0 & 0.0 & 6 & 2.4 \\
\hline LBBK & $1,10,14 a, 18$ & 1 & 2.3 & 2 & 3.6 & 9 & 6.3 & 0 & 0.0 & 12 & 4.7 \\
\hline MBGD & $1,3,11,14 a$ & 0 & 0.0 & 3 & 5.4 & 8 & 5.6 & 0 & 0.0 & 10 & 4.0 \\
\hline MBGJ & $1,3,11,10,14 a$ & 0 & 0.0 & 1 & 1.8 & 2 & 1.4 & 0 & 0.0 & 3 & 1.2 \\
\hline MBGK & $1,3,11,10,14 a, 18$ & 0 & 0.0 & 5 & 8.9 & 0 & 0.0 & 0 & 0.0 & 5 & 2.0 \\
\hline MBRD & $1,3,3 \mathrm{ka}, 11,30,14 a$ & 0 & 0.0 & 2 & 3.6 & 2 & 1.4 & 0 & 0.0 & 4 & 1.6 \\
\hline MBRJ & $1,3,3 \mathrm{ka}, 11,30,10,14 a$ & 0 & 0.0 & 1 & 1.8 & 0 & 0.0 & 0 & 0.0 & 1 & 0.4 \\
\hline MBRK & $1,3,3 \mathrm{ka}, 11,30,10,14 a, 18$ & 12 & 27.3 & 19 & 33.9 & 64 & 45.0 & 3 & 27.3 & 98 & 38.7 \\
\hline MCGJ & $1,3,26,11,10,14 a$ & 0 & 0.0 & 5 & 8.9 & 8 & 5.6 & 0 & 0.0 & 13 & 5.1 \\
\hline MCGS & $1,3,26,11, B, 10,14 a$ & 0 & 0.0 & 1 & 1.8 & 0 & 0.0 & 0 & 0.0 & 1 & 0.4 \\
\hline MCRJ & $1,3,26,3 \mathrm{ka}, 11,30,10,14 \mathrm{a}$ & 0 & 0.0 & 0 & 0.0 & 1 & 1.0 & 0 & 0.0 & 1 & 0.4 \\
\hline MCRK & $1,3,26,3 \mathrm{ka}, 11,30,10,14 a, 18$ & 0 & 0.0 & 4 & 7.1 & 5 & 3.5 & 1 & 9.1 & 10 & 4.0 \\
\hline MFRJ & $1,3,24,26,3 \mathrm{ka}, 11,30,10,14 a$ & 0 & 0.0 & 0 & 0.0 & 1 & 1.0 & 0 & 0.0 & 1 & 0.4 \\
\hline TBRJ & $1,2 a, 2 c, 3,3 \mathrm{ka}, 11,30,10,14 a$ & 0 & 0.0 & 0 & 0.0 & 6 & 4.2 & 0 & 0.0 & 6 & 2.4 \\
\hline TCRJ & $1,2 a, 2 c, 3,26,3 \mathrm{ka}, 11,30,10,14 a$ & 0 & 0.0 & 1 & 1.8 & 2 & 1.4 & 0 & 0.0 & 3 & 1.2 \\
\hline TDRJ & $\begin{array}{l}1,2 a, 2 c, 3,24,3 k a, 11,17,30,10 \\
14 a\end{array}$ & 0 & 0.0 & 0 & 0.0 & 1 & 1.0 & 0 & 0.0 & 1 & 0.4 \\
\hline TFGJ & $1,2 a, 2 c, 3,24,26,11,10,14 a$ & 5 & 11.4 & 1 & 1.8 & 0 & 0.0 & 0 & 0.0 & 6 & 2.4 \\
\hline TLGF & $1,2 a, 2 c, 3,9,11,14 a, 18$ & 11 & 25.0 & 11 & 19.6 & 20 & 14.0 & 6 & 54.5 & 48 & 33.8 \\
\hline TNRJ & $1,2 a, 2 c, 3,9,24,3 k a, 11,30,10,14 a$ & 9 & 20.5 & 0 & 0.0 & 0 & 0.0 & 1 & 9.1 & 10 & 4.0 \\
\hline Total isolates & & $\ldots$ & 44 & $\ldots$ & 56 & $\ldots$ & 142 & $\ldots$ & 11 & $\ldots$ & 253 \\
\hline
\end{tabular}


FBRT were found in the collections from Laurel Springs. These three virulence phenotypes were found in lower numbers or not all in the Coastal Plain and Piedmont locations. Phenotypes MBGD, MBRD, MCGJ, MFRJ, TBRJ, TCRJ, and TDRJ were only found in breeding plots in the Coastal Plain region. In collections from farm fields in the Coastal Plain of North Carolina, there were 14 isolates of phenotype MBRK, 7 isolates of TLGF, and 1 isolate each of FBMT and MCRK.

Virulence frequencies. Virulence to Lrl6 and Lrl7 was not found in any isolates from the South Atlantic region (Table 2). Virulence to $L r 14 a$ was found in all of the isolates. Over $90 \%$ of isolates across the region had virulence to $L r 1, L r 3$, and Lr11. Among isolates across the region, 40 to $74 \%$ had virulence to $L r 2 a, L r 2 c, L r 3 k a$, $L r 30, L r 10$, and $L r 18$. Virulence frequencies to genes $L r 9, L r 24, L r 26$, and $L r B$, were between 23 and $3.6 \%$ of isolates across the region.

Twenty-nine isolates of 16 different virulence phenotypes were tested for virulence to lines with adult plant resistance genes (Table 3). All isolates had high infection types on Thatcher $(\operatorname{Lr} 22 b)$. Six isolates (virulence phenotypes FBMT, FBRT, MBRD, TFGJ, and TNRJ) had high infection types on TcLr12, and the remaining isolates had low infection type. Only three isolates (FBMT, FBRT, and LBBK) had low infection type to TcLr13; the other isolates had high infection type. All isolates had lower infection type with fewer pustules on TcLr34 compared with Thatcher.

Twenty isolates, each with a different virulence phenotype, also were tested for virulence to the supplemental near-isogenic Thatcher lines. Every isolate had low infection types to lines with genes $L r 3 b g$, Lr19, Lr21, Lr25, Lr29, Lr32, Lr33, and Lr45. All isolates had high infection types to lines with $\operatorname{Lr} 14 b, \operatorname{Lr} 15, \operatorname{Lr} 20, \operatorname{Lr} 23$, and Lr28.

\section{DISCUSSION}

The widespread occurrence of virulence phenotypes MBRK and TLGF in the South Atlantic region indicates that these states generally should be considered as a single epidemiological unit for the wheat leaf rust pathogen. Much of the leaf rust inoculum in North Carolina and Virginia originates from urediniospores that arrive on the southerly winds from north Florida, Georgia, and South Carolina. Soft red winter wheats with combinations of leaf rust resistance genes $\operatorname{Lr} 2 a, \operatorname{Lr} 9, \operatorname{Lr} 10$, and $\operatorname{Lr} 11$ are grown throughout the region, which imposes a similar selection pressure in the

Table 3. Infection types on adult plants of near-isogenic Thatcher lines with resistance genes $\operatorname{Lr} 12$, Lr13, Lr34, and Lr22b (Thatcher) of representative Puccinia triticina isolates collected from the South Atlantic states in 1999

\begin{tabular}{|c|c|c|c|c|c|c|}
\hline \multirow[b]{2}{*}{ Isolate } & \multirow[b]{2}{*}{ Phenotype $^{b}$} & \multirow[b]{2}{*}{ State } & \multicolumn{4}{|c|}{ Thatcher line ${ }^{a}$} \\
\hline & & & TcLr22b & TeLr12 & TeLr13 & TcLr34 \\
\hline $31-3$ & FBMT & $\mathrm{NC}$ & 4 & 4 & ; & 23 \\
\hline $49-2$ & FBRT & $\mathrm{NC}$ & 4 & 4 & ; & 23 \\
\hline $87-3$ & KCGD & GA & 4 & 12 & 4 & 23 \\
\hline $66-1$ & LBBK & $\mathrm{NC}$ & 4 & $; 2$ & ;2 & 23 \\
\hline $21-4$ & MBGD & $\mathrm{NC}$ & 4 & 12 & 4 & 23 \\
\hline $23-1$ & MBGJ & $\mathrm{NC}$ & 4 & 12 & 4 & 23 \\
\hline $26-2$ & MBRD & $\mathrm{NC}$ & 4 & 4 & 4 & 23 \\
\hline $28-1$ & MBRK & $\mathrm{NC}$ & 4 & 12 & 4 & 23 \\
\hline $18-2$ & MBRK & $\mathrm{NC}$ & 4 & 12 & 4 & 23 \\
\hline $31-2$ & MBRK & $\mathrm{NC}$ & 4 & 12 & 4 & 23 \\
\hline $22-1$ & MBRK & $\mathrm{NC}$ & 4 & 12 & 4 & 23 \\
\hline $4-2$ & MBRK & $\mathrm{NC}$ & 4 & 12 & 4 & 23 \\
\hline $24-3$ & MCGJ & $\mathrm{NC}$ & 4 & 12 & 4 & 23 \\
\hline $102-1$ & MCGJ & $\mathrm{SC}$ & 4 & 12 & 4 & 23 \\
\hline $6-1$ & MCRJ & $\mathrm{NC}$ & 4 & 12 & 4 & 23 \\
\hline $58-5$ & MCRK & $\mathrm{NC}$ & 4 & 12 & 4 & 23 \\
\hline $32-2$ & MCRK & $\mathrm{NC}$ & 4 & 12 & 4 & 23 \\
\hline $24-2$ & TBRJ & $\mathrm{NC}$ & 4 & 12 & 4 & 23 \\
\hline $9-1$ & TBRJ & $\mathrm{NC}$ & 4 & 12 & 4 & 23 \\
\hline $7-2$ & TCRJ & $\mathrm{NC}$ & 4 & 12 & 4 & 23 \\
\hline $3-3$ & TCRJ & $\mathrm{NC}$ & 4 & 12 & 4 & 23 \\
\hline $96-3$ & TFGJ & GA & 4 & 4 & 4 & 23 \\
\hline $30-1$ & TLGF & GA & 4 & 12 & 4 & 23 \\
\hline $44-1$ & TLGF & $\mathrm{NC}$ & 4 & 12 & 4 & 23 \\
\hline $1-1$ & TLGF & $\mathrm{NC}$ & 4 & 12 & 4 & 23 \\
\hline $1-2$ & TLGF & $\mathrm{NC}$ & 4 & 12 & 4 & 23 \\
\hline $69-3$ & TLGF & VA & 4 & 12 & 4 & 23 \\
\hline $86-3$ & TNRJ & GA & 4 & 4 & 4 & 23 \\
\hline $67-2$ & TNRJ & VA & 4 & 4 & 4 & 23 \\
\hline
\end{tabular}

${ }^{\mathrm{a}}$ Infection types are identified as ; = hypersensitive flecks, $1=$ small uredinia with necrosis, $2=$ small uredinia with chlorosis, $3=$ moderate size uredinia, and $4=$ large uredinia.

b Virulence phenotype.

Table 2. Number and frequency (\%) of Puccinia triticina isolates virulent to Thatcher lines near-isogenic for leaf rust resistance genes in the South Atlantic States in 1999

\begin{tabular}{|c|c|c|c|c|c|c|c|c|c|c|}
\hline \multirow[b]{3}{*}{ Genes } & \multicolumn{10}{|c|}{ Isolates of Puccinia triticina } \\
\hline & \multicolumn{2}{|c|}{ Georgia } & \multicolumn{2}{|c|}{ South Carolina } & \multicolumn{2}{|c|}{ North Carolina } & \multicolumn{2}{|c|}{ Virginia } & \multicolumn{2}{|c|}{ Total } \\
\hline & No. & $\%$ & No. & $\%$ & No. & $\%$ & No. & $\%$ & No. & $\%$ \\
\hline Lrl & 39 & 88.6 & 56 & 100.0 & 129 & 90.8 & 11 & 100.0 & 235 & 92.9 \\
\hline $\operatorname{Lr} 2 a$ & 31 & 70.5 & 42 & 75.0 & 29 & 20.4 & 7 & 63.6 & 108 & 42.7 \\
\hline$L r 2 c$ & 31 & 70.5 & 42 & 75.0 & 42 & 29.5 & 7 & 63.6 & 121 & 47.8 \\
\hline $\operatorname{Lr3}$ & 43 & 97.7 & 54 & 96.4 & 133 & 93.6 & 11 & 100.0 & 241 & 95.3 \\
\hline $\operatorname{Lr} 9$ & 20 & 45.5 & 11 & 19.6 & 20 & 14.0 & 7 & 63.6 & 58 & 22.9 \\
\hline Lr16 & 0 & 0.0 & 0 & 0.0 & 0 & 0.0 & 0 & 0.0 & 0 & 0.0 \\
\hline $\operatorname{Lr} 24$ & 14 & 31.8 & 1 & 1.8 & 2 & 1.4 & 1 & 9.1 & 18 & 7.1 \\
\hline $\operatorname{Lr} 26$ & 11 & 25.0 & 12 & 21.4 & 17 & 11.9 & 1 & 9.1 & 41 & 16.2 \\
\hline Lr3ka & 21 & 47.7 & 27 & 48.2 & 95 & 66.9 & 4 & 36.4 & 147 & 58.1 \\
\hline Lr11 & 43 & 97.7 & 54 & 96.4 & 125 & 88.0 & 11 & 100.0 & 233 & 92.1 \\
\hline Lr17 & 0 & 0.0 & 0 & 0.0 & 0 & 0.0 & 0 & 0.0 & 0 & 0.0 \\
\hline Lr30 & 21 & 47.7 & 27 & 48.2 & 95 & 66.9 & 4 & 36.4 & 147 & 58.1 \\
\hline $\operatorname{LrB} B$ & 0 & 0.0 & 1 & 1.8 & 13 & 9.2 & 0 & 0.0 & 9 & 3.6 \\
\hline Lr10 & 27 & 61.4 & 44 & 78.6 & 40 & 64.7 & 5 & 45.5 & 168 & 66.4 \\
\hline Lr14a & 44 & 100.0 & 56 & 100.0 & 142 & 100.0 & 11 & 100.0 & 253 & 100.0 \\
\hline Lr18 & 24 & 54.5 & 41 & 73.2 & 111 & 78.1 & 10 & 90.9 & 186 & 73.5 \\
\hline Total isolates & 44 & $\ldots$ & 56 & $\ldots$ & 142 & $\ldots$ & 11 & $\ldots$ & 253 & $\ldots$ \\
\hline
\end{tabular}


different states. Wheat cvs. FFR 555W (Lr10), Saluda (Lrl1), Pocahontas (Lrl1), Jackson (Lrl, Lr11), and Pioneer 2580 (Lr11) (J. A. Kolmer, unpublished data), which have been grown from Georgia to Virginia, have selected for phenotype MBRK (virulences Lrl, Lr3, Lr3ka, Lrll, Lr30, Lr10, Lr14a, and Lr18) throughout the South Atlantic states. Most P. triticina phenotypes have virulence to genes $\mathrm{Lr} 10$ and LrII and cultivars with these genes have been widely grown in the South Atlantic region for several years.

Other current cultivars, such as FFR 518 (Lr9), FFR 522 (Lr9, Lr18), Coker 9474 (Lr2a, Lr9), Coker $9766(L r 2 a, L r 9)$, and especially Coker 9835 ( $\operatorname{Lr} 2 a, L r 9)$, also widely grown in the South Atlantic States in the late 1990s, have selected for phenotype TLGF (virulences $\operatorname{Lr} 1, \operatorname{Lr} 2 a, \operatorname{Lr} 2 c$, $L r 3, L r 9, L r 11, L r 14 a$, and Lr18). Virulence to $\operatorname{Lr} 9$, which is present in many soft red winter wheats, was found in 1999 in only two phenotypes, TLGF and TNRJ, in the South Atlantic region.

Coker 9663 ( $L r 2 a, L r 9$, and $L r 10$ ) has been the most commonly grown wheat in the southeastern states in recent years. Among the isolates in this study, only phenotype TNRJ (virulences $L r 1, L r 2 a, L r 2 c$, Lr3, Lr9, Lr3ka, Lr11, Lr30, Lr10, and Lr14a) has virulence to this cultivar. If Coker 9663 remains popular, then TNRJ may increase in frequency throughout the region, because it has virulence to $L r 2 a$, Lr9, and Lr10. Some advanced breeding lines and cultivars, such as Patton and Foster, have gene Lr26. Phenotypes with virulence to Lr26 (KCGD, MCGJ, MCGS, MCRJ, MFRJ, TCRJ, and TFGJ) occurred at lower frequencies. Although Lr26 conditions resistance to the current predominant isolates, the resistance of lines with $\operatorname{Lr} 26$ will inevitability be eroded as the frequency of phenotypes with virulence to this gene increase. Virulence to Lr26 in the Great Plains population of $P$. triticina increased shortly after the introduction of Siouxland wheat $(L r 24, L r 26)$ in the late 1980s (2).

Some less frequent virulence phenotypes of $P$. triticina were found mostly in localized areas, and were not generally distributed throughout the entire South Atlantic region. This could be attributed to populations of $P$. triticina that overwinter in localized areas or the effects of host selection within a localized area. Phenotype KCGD was found only in Plains, GA. This phenotype is unique in that it is avirulent to both $\mathrm{Lrl}$ and $\mathrm{LrlO}$, yet virulent to Lr26. A $P$. triticina population with this phenotype may have overwintered in the nurseries at Plains, or a breeding line may have specifically selected this phenotype. The higher number of virulence phenotypes obtained from the breeding nurseries in the Coastal Plain of North Carolina compared with phenotypes from farm fields can be attributed to the selective effects of additional leaf rust resistance genes such as $L r 18, L r 24$, and $L r 26$ in the breeding lines that were not present in the commonly grown commercial wheat cultivars.

Virulence surveys of the southeastern United States (from North Carolina and Florida to Arkansas and Louisiana) conducted by the United States Department of Agriculture-Agricultural Research Service Cereal Disease Laboratory (5), showed that MCRK, MBRJ, MBRK, and TLGF were the most common phenotypes in 1997 and 1998 in collections from breeding plots and farm fields. In 1996, MBRJ (with 37\% of isolates) was the most common phenotype in the region, while the other phenotypes that also were common in 1997 and 1998 occurred at less than $10 \%$. Since 1996, there has been an increase in P. triticina phenotypes with virulence to $\operatorname{Lr} 18$ in the southeastern region. This may have been caused by the use of cultivars with $\operatorname{Lr} 18$ in this region, such as cvs. FFR $522(\operatorname{Lr} 9$, Lr18), Pioneer 2684 (Lr10, Lrl8), and Coker 9803 (Lr10, Lr18).

In North Carolina, there was a distinct difference in distribution of virulence phenotypes from the Coastal Plain to the Mountain region. The collections from Laurel Springs in the Mountain region were distinct due to the higher frequency of phenotypes FBMT, FBRT, and LBBK. These phenotypes occurred at lower frequencies or not at all in the other two regions. The collections from Laurel Springs were made from susceptible wheat in early June, a month later than collections from the Coastal Plain and Piedmont regions. Phenotype LBBK is relatively avirulent and is probably restricted to wheat with Lr10, Lr18, or no resistance genes. The $P$. triticina population in the Mountain region of the South Atlantic states may be somewhat isolated from the major wheat-growing areas of the region, although phenotype MBRK also was collected at Laurel Springs.

Most of the P. triticina isolates tested to adult plant resistance genes were avirulent to lines with $\operatorname{Lr} 12$. This gene has most likely been present in the soft red winter wheat germ plasm ever since cv. Knox was released. Knox has Chinese Spring ( $\operatorname{Lr} 12$,
Lr31, and Lr34) (1) in its pedigree and it likely has LrI2 and Lr34. All of the isolates that were tested had smaller and fewer pustules on the Thatcher line with Lr34, compared with Thatcher. Lines and cultivars that have been genetically shown or postulated to have $\operatorname{Lr} 12, \operatorname{Lr} 34$, or both (Sturdy, Lr10, Lr12, Lr34; Monon, Lr12; Knox, Lr12, Lr34; and Bezostaya 1, Lr13, Lr34) had good leaf rust resistance in plots at Kinston, NC in 2000 (J. A. Kolmer, unpublished data). Genes Lr12 and Lr34 may condition the adult plant resistance in many current soft red winter wheats. Almost all isolates tested were virulent to Lr13. Wheat cvs. Coastal, Hadden, and Atlas 66, which have been postulated to have $\operatorname{Lrl3}$ (6), had severe leaf rust in plots at Kinston NC in 2000.

Leaf rust-resistant wheat cultivars that are grown in northern Florida and Georgia will select for $P$. triticina isolates, which then spread into South Carolina, North Carolina, and Virginia. The movement of $P$. triticina virulence phenotypes in the South Atlantic states is similar to the yearly northward spread of rust that occurs in the Great Plains region $(4,5)$. If cultivars are widely grown throughout the South Atlantic region, then selection of $P$. triticina isolates with virulence to resistance genes in wheat cultivars will occur at a faster rate. Effective leaf rust resistance may be prolonged by diversification of resistance genes in wheat cultivars that are commonly grown in this region.

\section{LITERATURE CITED}

1. Dyck, P. L. 1991. Genetics of adult-plant leaf rust resistance in 'Chinese Spring' and 'Sturdy' wheats. Crop Sci. 24: 309-311.

2. Kolmer, J. A. 1999 . Virulence dynamics, phenotypic diversity, and virulence complexity in two populations of Puccinia triticina in Canada from 1987-1997. Can. J. Bot 77:333338.

3. Long, D. L., and Kolmer, J. A. 1989. A North American system of nomenclature for Puccinia recondita f. sp. tritici. Phytopathology 79:525529.

4. Long, D. L., Leonard, K. J., and Hughes, M. E. 2000. Virulence of Puccinia triticina in the United States from 1996 to 1998. Plant Dis. 84:1334-1341.

5. Long, D. L., Leonard, K. J., and Roberts, J. J. 1998. Virulence and diversity of wheat leaf rust in the United States in 1993 to 1995. Plant Dis. 82: 1391-1400.

6. Roelfs, A. P. 1988. Resistance to leaf and stem rusts in wheat. Pages 10-22 in: Breeding Strategies for Resistance to the Rusts of Wheat. N. W. Simmonds and S. Rajaram, eds. CIMMYT, D.F., Mexico.

7. Samborski, D. J. 1985. Wheat leaf rust. Pages 39-59 in: The Cereal Rusts Vol. 2. A. P. Roelfs and W. R. Bushnell, eds. Academic Press, Orlando, FL. 